\title{
The Influence of Confucianism on East Asian Countries
}

\author{
Zixuan Liu \\ Dalian Neusoft University of Information \\ Dalian, China
}

\begin{abstract}
Confucianism has not only circulated in China for thousands of years, but also gradually spread to other East Asian countries with the prosperity of China. It has been rooted in people's values, culture and life. With the development of the times, it has been given new connotation and has had a profound influence on these countries. This thesis mainly studies the influence of Confucianism on the East Asian countries such as China, Japan and Korea from three aspects, values, corporate culture and marriage and family values, with a view to understanding the role of Confucianism in modern countries.
\end{abstract}

Keywords-Confucianism; East Asian countries; values; corporate culture; marriage and family values

\section{INTRODUCTION}

Confucianism has existed for two thousand years in East Asia, and it has always dominated the feudal dynasty. Although China has experienced the movement of "Criticizing Lin Biao, Criticizing Confucius" in 1970s, it has shaken the ruling position of Confucianism. But the idea spreading for thousands of years has been rooted in people's values, culture and life, and has been given a new connotation with the development of the times. On the other hand, with the prosperity of China, Confucianism gradually spread to other East Asian countries, and had a profound influence on the development of these countries. The East Asian countries such as Japan and South Korea, which were introduced and accepted Confucianism, preserved the Confucian thought that was even better than China to some extent, and preserved Confucian tradition more seriously than China.

\section{THE INFLUENCE OF CONFUCIANISM ON THE VALUES OF EAST ASIAN COUNTRIES}

The formation of values usually has two aspects of foundation. One is the geographical foundation, and the other is the cultural foundation. East Asian countries are adjacent to each other and have similar geographical environment, resulting in similar living habits. In addition, various thoughts based on Confucian culture have a profound impact on East Asia. East Asia is located in the circle of Confucian culture, which has been deeply influenced by Chinese Confucian thought since ancient times. Therefore, a set of unique values system has been formed, which is different from that of Western countries. It can be summed up as the collective culture of emphasizing family, nation and country, the importance of interpersonal relations, diligent and economic life management principle, and unceasing enterprising spirit. These principles can be traced back to Confucianism.

The formation of values in East Asian countries is deeply influenced by Confucian culture. First, attach importance to the interests of the group. Confucian culture has been advocating group interests and overall interests since ancient times, especially the group interests and the overall interests based on family, nation and country. This is totally different from the freedom and interests of individuals in Western values. Although Confucianism advocates freedom and interest, the freedom advocated by Confucianism is based on collective or overall freedom. In addition, Confucianism also values personal interests. But interest should be taken into account with morality. Confucius said, "a gentleman prefers to righteousness while a base person loves interests". Mencius once said, "life is what I value, and righteousness is what I want, and if I can't get both of them, I am willing to give up my life for righteousness". This concept of group interests and collective interests has affected the East Asia regions very early, especially, Japan and South Korea. In the Japanese and Korean enterprises, the enterprise culture, "taking enterprise as home" and "dedication for the enterprise", has played a vital role in the process of their modernization.

Second, emphasizes on the importance of interpersonal relationships. Confucian culture advocates "harmony is precious", so Confucius established an ideological system with "benevolence" as the core. Mencius also pointed out that "the weather is not as good as favorable geographical position, but the favorable geographical position is not as good as the harmony of people". Therefore, Confucianism advocates the concept of interpersonal relationship based on family ties. It is emphasized that "harmony" is very important in interpersonal relationships. Of course, this idea of "harmony is precious" can be applied not only to people but also to countries.

Third, emphasize the industrious and economic life management way. Confucian culture has always advocated that people should not blindly pursue material life, and but be industrious and frugal, indifferent to fame and wealth. Confucius once said, "luxury leads to arrogance, and economy will be poor. I prefer poverty to arrogance". In Singapore, for example, the former Prime Minister of Singapore, Li Guangyao, pointed out that "the main factors for the success of the Chinese people all over the world are frugality, industriousness and stamina, emphasis of education, community trust and mutual assistance. In a simple way, they 
are the core values of Chinese culture" in his speech at the opening ceremony of the world's first Chinese business conference. In addition, the diligence of the Japanese and Koreans is also recognized worldwide. According to statistics, Japanese people work on average 600 hours a year more than Americans. In the early development of Korea's economy, many people worked more than 10 hours a day.

Fourth, Confucianism emphasizes the importance of enterprising spirit. "The movement of heaven is strong and healthy, and accordingly, the gentleman should be strong and strive for progress and never stop". It is from Yi Jing. It describes an enterprising spirit of striving for selfimprovement. Confucian culture praises highly of this spirit. As we open our history book, we will find that East Asian countries have been ruled by other nations for a long time. After the Second World War, many countries have been devastating. But the East Asians rebuilt our homes on the ruins, creating the "East Asian Miracle", and made the whole world shocked. China rise rapidly as well as our economy after the reform and opening up, which is closely related to the unique values of Confucian culture in East Asia.

\section{THE INFLUENCE OF CONFUCIANISM ON THE Corporate Culture of EAST ASIAN COUNTRIES}

Since 1980s, the East Asian economy has been developing rapidly, especially in Japan, Korea and Singapore. Research shows that the main reason for the rapid economic growth in East Asia is that Confucianism plays an important role in corporate culture. The core values of Confucianism are "benevolence, righteousness, courtesy, wisdom and faith", and it emphasizes the responsibilities for enterprise and nation and the sacrifice spirit. Confucianism can be the motive force of the development of the eastern economy and create a road that is different from the capitalist economic development in the Western countries.

In Japan, take the world-famous Panasonic as an example to analyze the influence of Confucianism on Japanese enterprises. First of all, Japanese enterprises adhere to the social responsibility of "benefiting the country and serving the people". In ancient Chinese, "economy" means "to benefit the country and serve the people". Confucianism advocates the attitude of life that a social person should takes an active part in social activities. People should be honest in heart, be sincere to others, improve their accomplishments and keep their family harmonious. Japanese enterprises believe that the society is the foundation of the existence of the enterprise. In order to return to the society, the enterprise should serve the society and take the initiative to bear its own social responsibilities, which is the highest goal of Japanese enterprises. The goal of an enterprise shall be linked to the well-being of the country, society, and the people, so that employees will feel the mission they are given, and therefore are enthusiastic about the work they are engaged in. Konosuke Matsushita gained a lot of wealth through his successful management, but he paid the wealth back to society. He invested in a viaduct near Osaka station in 1964. In 1968, on the 50th anniversary of the Panasonic, he donated 5 billion yen as a research fund to prevent children from traffic accidents. In the same year, he invested and built factories in Kagoshima in order to promote the economic development of sparsely populated areas. In 1980, Panasonic and Konosuke Matsushita separately donated 5 billion yen as education fund. He practiced the social responsibility of "benefiting the country and serving the people".

Secondly, integrity is regarded as intangible asset of enterprises. Such intangible asset can comprehensively reflect the strength and credibility of enterprises, and will directly bring economic benefits to enterprises. Therefore, it is necessary to maintain integrity in both the company's employees, partners and customers. Konosuke Matsushita's famous glass management means open and transparent business activities, fully open to every employee, and welcomes employees to participate in the operation. Build mutual understanding in an open way, and it can not only improve employees' willingness to work, but also cultivate business leaders. In receiving customers, he is more faithful to the principle of good faith. He once said, "selling goods is like marrying a daughter". The enterprise should often contact with customers, provide after-sales service, and always concern about consumers' problems in purchasing goods. It is his sense of integrity that makes Panasonic last and shine.

Last, Japanese enterprises everywhere reflect the peopleoriented management concept. The starting point and ending point of Confucianism is human beings. Confucianism is knowledge of human beings. Confucius believed that man is the most important thing in heaven and earth. Mencius said, "people are the most precious, the state ranks second, and the kind ranks last". It is emphasized that only by putting people first can the state advance effectively and thrive. "People are the foundation of the country. Only people are peaceful and stabled, can the state be peaceful and prosperous". Konosuke Matsushita thinks that business is to train talents. Only by combining human intelligence with automation of machinery can we create more wealth. And we must cultivate talents before making goods. That's what he thought, and that's what he did. Panasonic Electronics attaches great importance to the training of employees. It has set up a special education and training center in the company, established the system of overseas study and regular rotation system to improve the staff's ability to work. In addition, the company also meets the requirements of the employees, such as shortening the working time, improving the working environment, improving the salary treatment, and trying not to lay off the staff when the business is difficult.

\section{THE INFLUENCE OF CONFUCIANISM ON VIEWS OF MARRIAGE AND FAMILY IN EAST ASIAN COUNTRIES}

Confucian thought of marriage and family ethics have had a profound influence on Chinese society and the family view of the East Asian countries since it was founded. To the highly developed society today, our family view still gives out the light of Confucian culture.

First of all, Confucianism was the earliest one to play an active role in maintaining and consolidating monogamy in the Spring and Autumn period and the Warring States period. They actively advocated the ethical thought of "affectionate father and dutiful son and friendly brothers". At that time, 
behaviors of father occupying daughter-in-law, and son and young brothers marrying wife of father, elder brother and uncle spread among the noble. But Confucianists rebuked them as absurdity. Xun $\mathrm{Zi}$ had ever inveighed against the primitive marriage for it endangered the society. He said: "if people don't cultivate themselves, and men and women have sexual relationship at will, son will suspect father, and father abandons son. Then family is destroyed, and adversity comes". In order to overcome the remnant of polygamous marriage, and stop men and women having sexual relationship at will, Confucianists attach importance to the standard role of the wedding ceremony and emphasize "a right and legal marriage". In other words, one marries into somebody's house in an open, correct manner. "The command of parents and the introduction of matchmaker" became a necessary way for men and women to unite. It has played its positive role in the history. But it also has restricted the free love combination of young men and women, which has also led to many human tragedies. However, with the progress of the society, we keep it as a way to find a partner. By taking its essence to its dross, it still plays its positive role today.

Secondly, the Korean family view is also deeply influenced by Confucianism. The Koreans have high loyalty to their families. The Korean marriage and family still abide by the Confucian admonition of "loyalty and filial etiquette". The Koreans believe that each person lives in the world and should take on the responsibilities of marriage and family. Family members love each other and seldom betray. Korean family play is a true portrayal of the life of Korean people. Through these family plays, it is seen that the Koreans attach importance to family, and everyone is striving for their family. If a third person destroys others' marriage and family, she/he often fails to get happiness and will eventually be rewarded. As the cornerstone of Confucian culture, filial piety occupies a dominant position in Korean spiritual and cultural life. In the family of Korea, the responsibilities of the eldest son and grandson are especially important and great. The eldest son and grandson must live with his parents and seniors, and bear the responsibility of supporting the elderly. The elder daughter-in-law also shall take all labor of the family. In addition, the etiquette between the young and the elder is very much. For example, the younger generation shall use the honorific words to the elders, cannot crash against the elders, and follow the opinions of the elders in all the matters in the family.

Confucian marriage and family ethics play a positive role on the one hand, but on the other hand, there are certain limitations. It mainly manifests in maintaining the idea of "men are superior to women" and boosts the unequal status of men and women in marriage. It restricts women's thoughts and deeds with "three obedience and four virtues". It identifies and maintains the concept of "men are superior to women" and "women shall follow the opinions of men". The wrong concept of marriage was greatly advocated by the feudal governments of Yuan and Ming Dynasties, quickly dominating the marriage at that time. For a long time it seriously hinder the healthy development of marriage and family. Today, the idea of "men are superior to women" has been greatly changed in China, and only some remote mountain villages still keep it. Compared with China, Japanese are still deeply affected by the idea of "men are superior to women". This may be because women in China, especially in the cities, still need work after marriage, and only some remote mountain villages still keep it. Chinese women are contributors to family income, so it is easy for them to get equal family status. While most Japanese women will quit their jobs to take care of their families after marriage, they are unable to obtain income or obtain roughly equal income from men, which make them subordinate to their marriage. However, it is Korea who is greatest affected by this concept. South Korea's former president, Park Geun hye, came up with the idea of "eradicating four major social cancers", including family violence. South Koreans are complicated in blood ties. In some areas, in school and work, they have complicated relationship. The young are often reprimanded by parents or elders, and some men tend to vent their anger on their wives, and even someone believes "wife will become a fox without being beaten for 3 days". It is evident to see the status of Korean women in marriage.

\section{CONCLUSION}

The integration of Confucianism into the spirit of the Chinese nation was concentratedly embodiment of excellent thoughts of the Chinese nation, and it was also recognized and accepted by the East Asian countries. After thousands of years of inheritance, Confucian thought still has an impact on people's life, values, social economy and enterprise culture. Confucian thought has its historical limitation, but with the progress of the society, people will take its essence to its dross, so that the excellent thought will continue to flourish in the world.

\section{REFERENCES}

[1] Zhang Liyang. Functions of Confucian Culture in Reconstruction of East Asian Values. Yanbian University, 2010 (5). 张立阳.儒家文化在 东亚价值观重构中的作用[D].延边大学, 2010（5）

[2] Zhang Jingbo. Influence of Confucianism on the Corporate Culture of East Asian Countries. Tianjin University of Finance Economics, 2009 (5). 张晶波.论儒家思想对东亚国家企业文化的影响 [D].天津财经大 学, 2009 (5)

[3] Yin Yue. Confucian Culture in Korean. Chifeng University Journal (Chinese Philosophy and Social Sciences Edition), 2011 (9): 105-105. 尹悦.儒家文化在韩国 [J].赤峰学院学报（汉文哲学社会科学版）, 2011 (9) : 105-105

[4] Lv Ruquan. Influence of Chinese Culture on Japanese Traditional Culture. Journal of Hubei University of Economics (HUMANITIES AND SOCIAL SCIENCES EDITION), 2014 (7): 96-97. 吕汝泉.略论 中国文化对日本传统文化的影响 [J].湖北经济学院学报（人文社会 科学版) 2014 (7) : 96-97

[5] Chen Bing, Zhang Xiaowei. The Influence of Confucianism on the Marriage and Family System in China. Journal of the Party School of Zhengzhou Municipal Party Committee, 2004 (6): 98-99. 陈冰, 张小 伟. 儒家思想对中国婚姻家庭制度的影响[J].中共郑州市委党校学报, 2004 (6) : 98-99 